\title{
Molybdenum (VI) Binded to Humic and Nitrohumic Acid Models in Aqueous Solutions. Salicylic, 3-Nitrosalicylic, 5-Nitrosalicylic and 3,5 Dinitrosalicylic Acids, Part 2
}

\author{
Ana Lucia R. Mercê, ${ }^{*, a}$ Priscilla P. Lopes, ${ }^{a}$ Antonio S. Mangrich ${ }^{a}$ and Noel M. Levy ${ }^{b}$ \\ ${ }^{a}$ Departamento de Química, Centro Politécnico, Universidade Federal do Paraná CP 19081, \\ 81531-990 Curitiba-PR, Brazil \\ ${ }^{b}$ Companhia Paranaense de Energia (COPEL), Curitiba - PR, Brazil
}

\begin{abstract}
Apresentam-se neste trabalho, estudos eletroquímicos e espectroscópicos na região do Ultravioleta-Visível de modelos derivados do ácido salicílico de ácidos húmicos e nitrohúmicos, esse último um artefato laboratorial, na presença de molibdênio para determinar a afinidade desses modelos com esse íon metálico. Molibdênio tem um papel importante na química de solo e conjuntamente com as substâncias húmicas, promove fertilidade ao solo e água e é um elemento chave na enzima nitrogenase. Os resultados obtidos mostraram que pelo menos uma espécie complexada está presente na faixa de $\mathrm{pH}$ 6,3 a 8,0, mesmo para o modelo menos básico escolhido, dos ácidos nitrossalicílicos. Estudo anterior mostrou que modelos derivados do ácido ftálico e nitroftálico, modelos também para os ácidos húmicos e nitrohúmicos, apresentaram espécies complexadas apenas até $\mathrm{pH}$ 6,5. As constantes de formação calculadas mostraram que a substituição do grupamento nitro na posição orto desfavorece a complexação, quando comparada à substitução para, devido provavelmente ao impedimento estérico no primeiro caso, uma vez que esse impedimento se manifesta indubitavelmente no composto duplamente substituído com o grupamento nitro. Os espectros obtidos por voltametria cíclica e por espectroscopia no Ultravioleta-Visível mostraram que a química do molibdênio em solução aquosa é muito complexa com a variação do $\mathrm{pH}$, e que o ânion molibdato deixa de ser um ânion em valores de $\mathrm{pH}$ próximos a 4 , quando então passa a se comportar como cátion, $\mathrm{MoO}_{2}{ }^{2+}(\mathrm{M})$.
\end{abstract}

In this work electrochemical and Ultraviolet-Visible studies were performed in solutions of salicylic acid models of humic and nitrohumic acids, a laboratory artifact, and molybdenum in order to determine the affinity of these models towards the metal ion. Molybdenum, which plays a very important role in the soil chemistry, and together with humic substances, impart fertility to soil and water and is a key element in the activity of nitrogenase. The obtained results showed that at least one complexed species is present at the $\mathrm{pH}$ range of 6.3 to 8.0, even for the less basic chosen models, the nitrosalicylic acids. Previous study showed that phthalic and nitrophthalic, also humic and nitrohumic acids model compounds, presented complexed species with molybdenum only till $\mathrm{pH}$ 6.5. The calculated formation constants showed that the substitution of the nitro group in the orto position was less favoured than in the para substitution, probably due to a steric hindrance in the former, which was clearly seen in the double substituted salicylic nitro derivative. The cyclic voltammetry as well as the Ultraviolet-Visible obtained spectra were able to show that the chemistry of molybdenum in aqueous solutions as the $\mathrm{pH}$ is increased is very complex, and the molybdate stops acting as an anion only after $\mathrm{pH}$ around 4 , when it finally becomes a cation $\mathrm{MoO}_{2}{ }^{2+}(\mathrm{M})$.

Keywords: humic acid models, molybdenum (VI), potentiometric titration, stability constants, slow release fertilizer, electrochemistry, complexation, UV-Vis

\section{Introduction}

Chemistry of soil molybdenum (Mo) plays an important role in reactions where the nitrogenase enzyme is involved.

* e-mail: anamerce@ufpr.br
Thus, each Mo acts as a separate catalytic center and is a significant redox enzyme essential for microorganisms, plants and animals. At the centre of the nitrogenase enzyme is the FeMo cofactor, where the actual reduction of dinitrogen takes place. The Mo-Fe-S is biologically important in nitrogen fixation catalysed by nitrogenases. 
One of its component is the Mo-Fe protein which contains a unique Fe-Mo-S cluster, which is believed to be the active site for the dinitrogen reduction. Figure 1 presents a structure of this nitrogenase FeMo cofactor where after core rearrangement there is the formation of two isomers $\left(\mathrm{Mo}_{2} \mathrm{Fe}_{6} \mathrm{~S}_{9}\right)$, having Mo or Fe as the metal ion. ${ }^{1}$

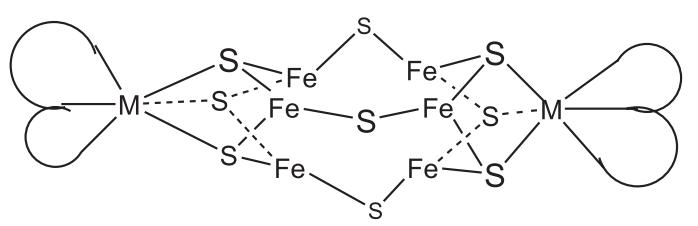

Figure 1. A proposed structure of a model of nitrogenase's cofactor.

The molybdate anion undergoes certain reactions where there is the breakage of $\mathrm{M}=\mathrm{O}$ bond. Some examples of such reactions are presented by the following equations: ${ }^{2}$

$$
\begin{aligned}
& \mathrm{MoO}_{3}+\mathrm{H} \text {-bonding ligand } \rightleftharpoons \text { complex H-bonded } \\
& \mathrm{MoO}_{3}+\text { chelating agent } \rightleftharpoons \mathrm{MoO}_{3} \mathrm{~L} \\
& \mathrm{MoO}_{3}+\text { chelating agent } \rightleftharpoons \mathrm{MoO}_{2} \mathrm{~L}
\end{aligned}
$$

The dominant aqueous Mo species will depend on the equilibria as well as on the $\mathrm{pH}$ values. The anion $\mathrm{MoO}_{4}^{2-}$ undergoes the formation of many different polyanions in acidic solutions, particularly at $\mathrm{pH} 4.1$ where there are the existence of both para $\mathrm{Mo}_{7} \mathrm{O}_{24}{ }^{6-}$ molybdate and octa $\mathrm{Mo}_{8} \mathrm{O}_{26}{ }^{4-}$ molybdate anions. The formation of polyanions may be represented as in equations 4 and 5:3,4

$$
\begin{aligned}
& 8 \mathrm{H}^{+}+7 \mathrm{MoO}_{4}^{2-} \rightleftharpoons \mathrm{Mo}_{7} \mathrm{O}_{24}{ }^{6-}+4 \mathrm{H}_{2} \mathrm{O} \\
& 12 \mathrm{H}^{+}+8 \mathrm{MoO}_{4}^{2-} \rightleftharpoons \mathrm{Mo}_{8} \mathrm{O}_{26}{ }^{4-}+6 \mathrm{H}_{2} \mathrm{O}
\end{aligned}
$$

When a dilute solution of $\mathrm{MoO}_{4}{ }^{2-}\left(<10^{-4} \mathrm{~mol} \mathrm{~L}^{-1}\right)$ is acidified it yields $\mathrm{HMoO}_{4}^{-}$and $\mathrm{H}_{2} \mathrm{MoO}_{4}$. The tetrahedral ion $\mathrm{MoO}_{4}{ }^{2-}$ transforms into an octahedral species at the second stage of protonation according to equations 6 and $7: 3$

$$
\begin{aligned}
& \mathrm{MoO}_{4}{ }^{2-}+\mathrm{H}^{+} \rightleftharpoons\left[\mathrm{MoO}_{3}(\mathrm{OH})\right]^{-} \\
& {\left[\mathrm{MoO}_{3}(\mathrm{OH})\right]^{-}+\mathrm{H}^{+}+2 \mathrm{H}_{2} \mathrm{O} \rightleftharpoons \mathrm{Mo}(\mathrm{OH})_{6} \text { or }} \\
& \mathrm{MoO}_{2}(\mathrm{OH})_{2}\left(\mathrm{H}_{2} \mathrm{O}\right)_{2}
\end{aligned}
$$

At $\mathrm{pH}$ values higher than 4 the most important species is $\mathrm{MoO}_{2}{ }^{2+}$, when molybdenum is chemically acting as a cation according to previous equations 3 and $7 . .^{3-5}$

Soil organic matter $(\mathrm{OM})$ promotes soil aggregation and its chemical function is recognized by its ability to interact with metals, oxides, metal hydroxides and mineral clays to form organometallic complexes. Soil OM improves N, P, and $\mathrm{S}$ bioavailability, therefore it has the potential use as a slow release fertilizer. The OM is very heterogeneous and it can be functionally grouped into nonhumic (carbohydrate, proteins, fats, waxes, etc) and humic structures. ${ }^{6}$

It is widely stated in the literature that soil humic acid (HA) composition is dependent on soil composition and organic precursors, resulting in differences in HA molecular mass and chemical structures. Consequently metal binding will vary with HA sources. ${ }^{7-13}$

Soil fertility plays a role by improving metal ion mobility and transport in the environment. ${ }^{11-12,14-16}$ Cation binding to humic substances include the extreme binding heterogeneity of these natural materials, the variable stoichiometry of binding, the competition between specifically-bound ions, especially protons and metal ions, and electrostatic effects which give rise to ionic strength effects and the non specific binding of couterions. ${ }^{17}$ All the mathematical models presented in the literature so far ${ }^{18-25}$ cannot deal with all those parameters, sometimes employing empirical equations and bacterial and HA competition. Also the complexation of metals by heterogeneous ligands is dependent on metal loading (the rate of bound metal to the binding site concentration). To overcome some of these difficulties this study deals with some molecular models of HAs according to the sorption sites following others in the literature ${ }^{5,26-28}$ presenting data on those HAs main sorption sites that can reliably be used in those mathematical models as well as the speciation along a wide range of $\mathrm{pH}$ values.

Although higher valence cations such as molybdenum ions can undergo either hydrolysis or ligand binding, potentiometric titrations can provide the conditional stability constants as a way to try to understand how biological systems binds so selectively to ligands or metal ions. The study of model compounds has to be in such a way that they represent properly the known physical and chemical properties of the basic sites of the complex structure of the substance under investigation. Such is the case for humic and nitrohumic acids, geopolymers mainly composed of phenolic hydroxyl groups, hydroxycarboxylic and carboxylic aromatic groups as basic sites. ${ }^{7-9}$

Therefore, in this work the $\mathrm{MoO}_{4}^{2-}$ anion was chosen to be studied with the humic and nitrohumic acid models salicylic and nitro-salicylic acids. The nitrohumic acids are a laboratory artifact. Although the high oxidation species of molybdenum (such as in molybdate) is not the only one involved in the biological reactions, it is water soluble and undergoes many interconvertible reactions (refer to equations 1 to 7 ). It is possible to determine how the $\mathrm{pH}$ values changes can act on the equilibrium of all species. In order to determine 
all equilibrium possibilities, it was performed potentiometric, cyclic voltammetric (CV) and ultraviolet-visible (UV-Vis) titrations. A previous work reports a study with this same metal ion with models of phthalic, nitro-phthalic, catechol and nitro-catechol humic acids-like sorption or basic sites. ${ }^{5}$

\section{Experimental}

\section{Materials}

All chemicals were used without further purification. The supporting electrolyte $\mathrm{KCl}$ (J.T.Baker - USA) was used to maintain ionic strength (I) at $0.100 \mathrm{~mol} \mathrm{~L}^{-1}$. Aqueous 95\% (v/v): 5\% (v/v) ethanolic (Merck - Brazil) solutions (approximately $0.1 \mathrm{~mol} \mathrm{~L}^{-1}$ ) of the ligands salicylic acid (SALA - Reagen - Brazil), 3-nitrosalicylic acid, 5-nitrosalicylic acid and 3,5-dinitrosalicylic acid (3NSA, 5-NSA and 3,5-DNSA, respectively, TCI - Japan), and $0.1 \mathrm{~mol} \mathrm{~L}^{-1} \mathrm{KOH}$ (Merck - Brazil) were prepared in double distilled and deionized, carbonate - free water. The $\mathrm{KOH}$ solutions were standardized against potassium acid phthalate.

A proper mass of $\mathrm{NH}_{4} \mathrm{Mo}_{7} \mathrm{O}_{24} \cdot 4 \mathrm{H}_{2} \mathrm{O}$ (Carlo Erba - Italy) was dissolved in water and its content was measured by back titration with disodium edetate (Carlo Erba - Italy) following the literature. ${ }^{29}$

\section{Potentiometric equilibrium measurements}

Following the procedures described in the literature ${ }^{30}$ the errors arising in calculating unknown equilibrium constants by least-square techniques were minimized. Three titrations were performed with the metal ion and each ligand for all metal to ligand ratios analysed. The potentiometric studies were carried out in a Micronal (model B-375 - Brazil) pH meter fitted with a glass and a calomel reference electrode calibrated with standard $\mathrm{HCl}, 10^{-2} \mathrm{~mol} \mathrm{~L}^{-1}\left(\mathrm{I}=0.100 \mathrm{~mol} \mathrm{~L}^{-1}\right.$ $(\mathrm{KCl})$ ) and $\mathrm{KOH}$ solutions to read -log of the concentration of $\mathrm{H}^{+}(\mathrm{pH})$ directly, under a $\mathrm{KOH}$ - aqueous saturated stream of $\mathrm{N}_{2}$ (White-Martins - Brazil) and recording the $\mathrm{pH}$ values only after stabilization. The $\mathrm{pH}$ reproducibility was $<0.005$ $\mathrm{pH}$ at acidic $\mathrm{pH}$ region and $<0.015 \mathrm{pH}$ at the basic $\mathrm{pH}$ region. The temperature was maintained at $25.0 \pm 0.1{ }^{\circ} \mathrm{C}$ (Microquímica - MQBCT - 99-20, Brazil) and the ionic strength adjusted to $0.100 \mathrm{~mol} \mathrm{~L}^{-1}$ with $\mathrm{KCl}$.

\section{Calculations}

The protonation constants of the ligands employed were reported previously ${ }^{26,27}$ according to equations 8 and 9 with charges omitted for simplicity.

$$
\begin{aligned}
& \mathrm{L}+\mathrm{H} \rightleftharpoons \mathrm{HL} \quad \log \mathrm{K}_{1}=[\mathrm{HL}] /[\mathrm{L}][\mathrm{H}] \\
& \mathrm{HL}+\mathrm{H} \rightleftharpoons \mathrm{H}_{2} \mathrm{~L} \quad \log \mathrm{K}_{2}=\left[\mathrm{H}_{2} \mathrm{~L}\right] /[\mathrm{HL}][\mathrm{L}]
\end{aligned}
$$

The hydrolysis constants of molybdenum (VI) were taken from the literature. ${ }^{31,32}$ The species considered in the calculations were metal to ligand ratios (metal being $\mathrm{MoO}_{2}{ }^{2+}$, herafter represented as $\mathrm{M}$, and ligand = salicylate derivatives, hereafter represented as $L$ ) of $1: 1,1: 2 ; 2: 1$; $2: 2 ; 1: 3 ; 2: 4$ and their protonated counterparts as well as any possible $\mu$-oxo compounds.

The calculations were made with Best7 program and species distributions were calculated with SPE program. 5,30

Aware of the region where the uptaking of protons by molybdate is seen, only when $\mathrm{MoO}_{2}{ }^{2+}$ cations were present the calculations began. This initial portion of the $\mathrm{pH}$ profiles produced no complexed species rather than polyanions, under the experimental conditions employed. The mathematical model for the calculations took into account the possible rates of bound metal to the binding site concentration (the metal loading parameter $)^{5}$ in order to simulate an heterogeneous ligand such as humic and nitrohumic substances, the hydrolysis constants of molybdenum ions $\mathrm{s}^{31,32}$ and the standardized concentrations of $\mathrm{KOH}$ - the titrant employed - and the concentration of the mineral acid $\left(\mathrm{HNO}_{3}\right)$ added when necessary.

\section{Cyclic voltammetry}

The cyclic voltammetric measurements were obtained with a cyclic voltammeter (Bioanalytical Systems Inc. - USA, model CV-27). A three electrode system was utilized: vitreous carbon as the working electrode, saturated $\mathrm{Ag} / \mathrm{AgCl}-\mathrm{KCl}$ as the reference and a platinum wire, the auxiliary electrode. The voltammograms were obtained in aqueous solutions, at room temperature of $25{ }^{\circ} \mathrm{C}$, in ionic strength of $0.10 \mathrm{~mol}$ $\mathrm{L}^{-1}\left(\mathrm{NaNO}_{3}\right)$, and bubbled with ultra pure argon at $\mathrm{pH}$ range of 2.5 to 10.0. The initial solutions were acidified with $\mathrm{HNO}_{3}$ ( $0.1 \mathrm{~mol} \mathrm{~L}^{-1}$ ) and titrated with $\mathrm{KOH} 0.1 \mathrm{~mol} \mathrm{~L}^{-1}$ delivered by a microburet (Gilmont - USA) until the desired $\mathrm{pH}$ was reached. The cyclic voltammograms were obtained as a function of each $\mathrm{pH}$ value measured with a $5 \mathrm{~mm}$ diameter combined glass and $\mathrm{Ag} / \mathrm{AgCl}$ reference electrode (Analyser - Brazil) and a Corning $\mathrm{pH}$ meter (UK), at an accuracy of $0.01 \mathrm{pH}$ units. The final concentration in the reaction cell for all solutions was $10^{-4} \mathrm{~mol} \mathrm{~L}^{-1}$ and the ligand to metal ratios were $1: 1,2: 1$ and $3: 1$. The experimental conditions of the cyclic voltammograph were as follows. The optimum range of swept potential was from $0.0 \mathrm{~V}$ to $-1.1 \mathrm{~V}$. All scans were made from -1.1 to $1.0 \mathrm{~V}$; the scan-rate $=10 \mathrm{mV} \mathrm{s}^{-1}$; and initial potential applied $=0.0 \mathrm{~V}$. 


\section{Ultraviolet-Visible spectra}

Separated spectrophotometric titrations were carried out with the ligands alone and in the presence of the molybdate starting solution. By following the $\mathrm{pH}$ values where there is the presence of complexed species, aliquots were taken and analysed by UV-Vis spectroscopy and it was possible to monitor the formation and decomposition of species in the equilibria studied.

The UV-Vis spectra were recorded on a HewlettPackard model 8450-A diode array spectrophotometer (USA) in the range of 190-600 nm. Aliquots of about 3.0 $\mathrm{mL}$ of a separate titration in the ratios of 1:1, 1:2: 1:3 metal to ligand were performed in a quartz cell $(1.000 \mathrm{~cm}$ path length) appropriately coupled to a $10 \mathrm{~mL}$ vessel where the $\mathrm{pH}$ values were adjusted by adding small volumes of $\mathrm{KOH}\left(0.1 \mathrm{~mol} \mathrm{~L}^{-1}\right)$ and measured accordingly to cyclic voltammetry section.

\section{Results and Discussion}

Potentiometric titration profiles of the ligands (L) SALA, 5-NSA and 3,5-DNSA are presented in Figures 2 to 4 in the absence and in the presence of $\mathrm{M}$ in three different metal to ligand ratios. 3-NSA (Figure not shown) ligand presented very similar $\mathrm{pH}$ profiles with $\mathrm{M}$ as 5-NSA. The main striking feature of these profiles in the presence of metal is that at the beginning of the titrations, specially when the proportion favours the higher concentration of metal ion, the molybdate, an anion, first takes protons from the system, and then at $\mathrm{pH}$ values around 4.5 or greater, starts to act like a cation, by then complexing with the ligands. ${ }^{32}$ Although the $\mathrm{ML}_{3}$ species is highly thermodinamically unfavoured, potentiometric titration ratio $\mathrm{M}: \mathrm{L}$ of 1:3 was conducted, but it was not possible to detect this species in percentages above $10 \%$ as required for the mathematical and chemical models employed in this study. ${ }^{30}$ Formation constants for the complexed species were derived from the potentiometric data and are shown in Table 1.

Looking at the values in Table 1 the non nitro ligand (SALA) has greater binding affinity among the four studied ligands because the electrons of the potentially binding

Table 1. Logarithms of the formation constants of molybdenum (VI) complexes and humic and nitrohumic acid like models $(\mathrm{L}) . \mathrm{T}=25.0^{\circ} \mathrm{C}$, $\mathrm{I}=0.100 \mathrm{~mol} \mathrm{~L}^{-1}$

\begin{tabular}{lcccc}
\hline Species & \multicolumn{4}{c}{$\log \mathrm{K} \pm 0.1$} \\
& SALA & 5-NSA & 3-NSA & 3,5-DNSA \\
\hline$[\mathrm{ML}] /[\mathrm{M}][\mathrm{L}](1: 1)$ & 12.9 & 9.7 & 7.7 & 6.5 \\
{$[\mathrm{MHL}][\mathrm{ML}][\mathrm{H}]$} & 4.4 & 4.3 & 4.3 & 4.1 \\
{$\left[\mathrm{ML}_{2}\right] /[\mathrm{ML}][\mathrm{L}](1: 2)$} & 6.9 & 6.4 & 3.5 & 3.6 \\
\hline
\end{tabular}

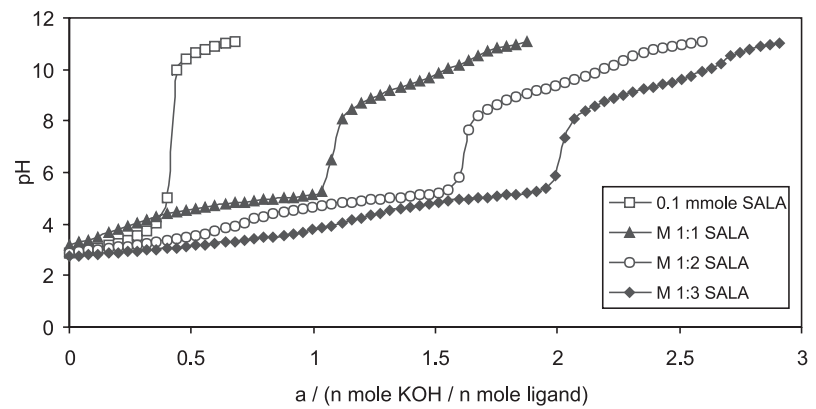

Figure 2. Potentiometric $\mathrm{pH}$ profile of molybdenum (VI) (M) and SALA (L). $\mathrm{T}=25.0^{\circ} \mathrm{C}, \mathrm{I}=0.100 \mathrm{~mol} \mathrm{~L}^{-1}$.

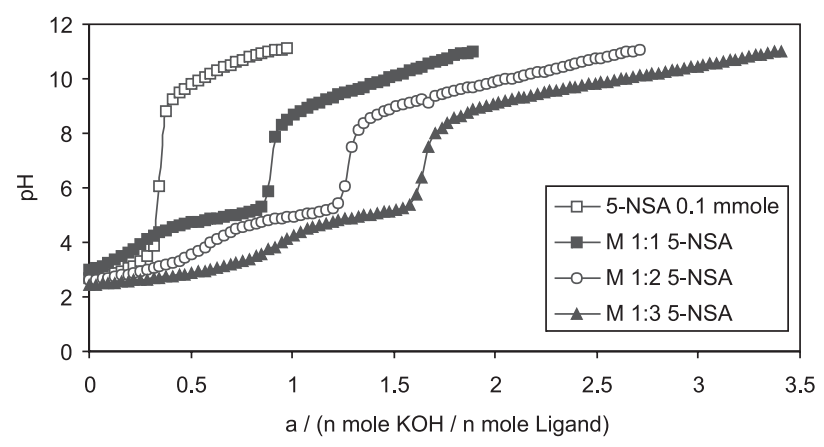

Figure 3. Potentiometric pH profile of molybdenum (VI) (M) and 5-NSA (L). $\mathrm{T}=25.0^{\circ} \mathrm{C}, \mathrm{I}=0.100 \mathrm{~mol} \mathrm{~L}-1$.

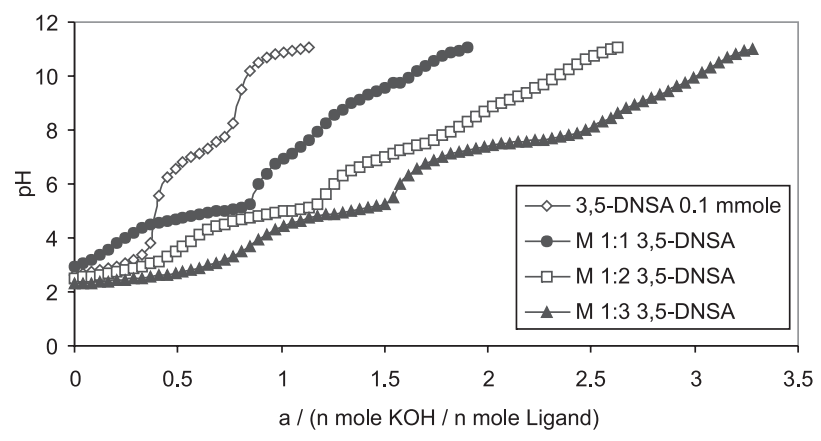

Figure 4. Potentiometric pH profile of molybdenum (VI) (M) and 3,5DNSA (L). $\mathrm{T}=25.0{ }^{\circ} \mathrm{C}, \mathrm{I}=0.100 \mathrm{~mol} \mathrm{~L}^{-1}$.

sites (carboxylic and phenolic groups) are not involved in the resonance effect of the aromatic ring. Such is not the case of the nitro ligands (NSA's) since the electron withdrawing effect of the $-\mathrm{NO}_{2}$ substituent pulls the electron from the binding groups towards the aromatic ring and consequently depleting the basicity effect of these groups. In addition when the $-\mathrm{NO}_{2}$ group is in C-3 (3NSA and 3,5-DNSA) there is the stereochemical influence in the formation of $\mathrm{ML}$ and $\mathrm{ML}_{2}$, making the complexation a little less favoured compared to when the electron pulling group is in para position (5-NSA). Both $\mathrm{ML}$ and $\mathrm{ML}_{2}$ logarithms of the formation constants showed this trend. 
Table 2. Cathodic peak potentials of molybdenum (VI) complexes where humic acid models are the ligands (L) at 1:1 and 1:2 ratios of metal to ligand

\begin{tabular}{lccccc}
\hline \multirow{2}{*}{ Species } & \multicolumn{5}{c}{$\mathrm{E}_{\mathrm{pc}}(\mathrm{V} v s . \mathrm{SCE})$} \\
& $(\mathrm{NH} 4)_{2} \mathrm{MO}_{2}$ & $\mathrm{~L}=\mathrm{SALA}$ & $\mathrm{L}=5-\mathrm{NSA}$ & $\mathrm{L}=3-\mathrm{NSA}$ & $\mathrm{L}=3,5-\mathrm{DNSA}$ \\
$\mathrm{M}$ & -0.584 & & & & \\
$\mathrm{~L}$ & & $*$ & -0.687 & -0.594 & -0.482 \\
{$[\mathrm{ML}]-(1: 1)$} & & -0.489 & -0.494 & -0.485 & -0.476 \\
{$\left[\mathrm{ML}_{2}\right]-(1: 2)$} & & -0.507 & -0.532 & -0.504 & -0.489 \\
\hline
\end{tabular}

* non electroactive ligand.

In the species distribution diagrams (Figures not shown) there was at least one complexed species at $\mathrm{pH}$ near 6.5 and until $\mathrm{pH} 8$, for each ligand tested.

The cyclic voltammetric titrations added only limited information due to the irreversibility of the obtained voltammograms. In Figure 5 it is shown the voltammograms of all ligands, $10^{-4} \mathrm{~mol} \mathrm{~L}^{-1}$. SALA is not electroactive and the salt $\left(\mathrm{NH}_{4}\right)_{2} \mathrm{MO}_{2}$ is pseudoreversible at acidic $\mathrm{pH}$ values. All ligands caused a $\mathrm{pH}$ dependent cathodic peak $\left(\mathrm{E}_{\mathrm{pc}}\right)$, but the definition became lower with the increased $\mathrm{pH}$. At very high $\mathrm{pH}$ values the voltammograms lost their original shape and the $\mathrm{E}_{\mathrm{pc}}$ wave was no longer shown. All voltammograms showed a second wave at $\sim 0.95 \mathrm{~V}$ that was assigned to amine group formation and does not undergo an oxidation process at the cathodic sweep (positive portion of the voltammogram not shown). The irreversibility may be due to the reduction of the nitro group, according to what occurs to nitrobenzene, which

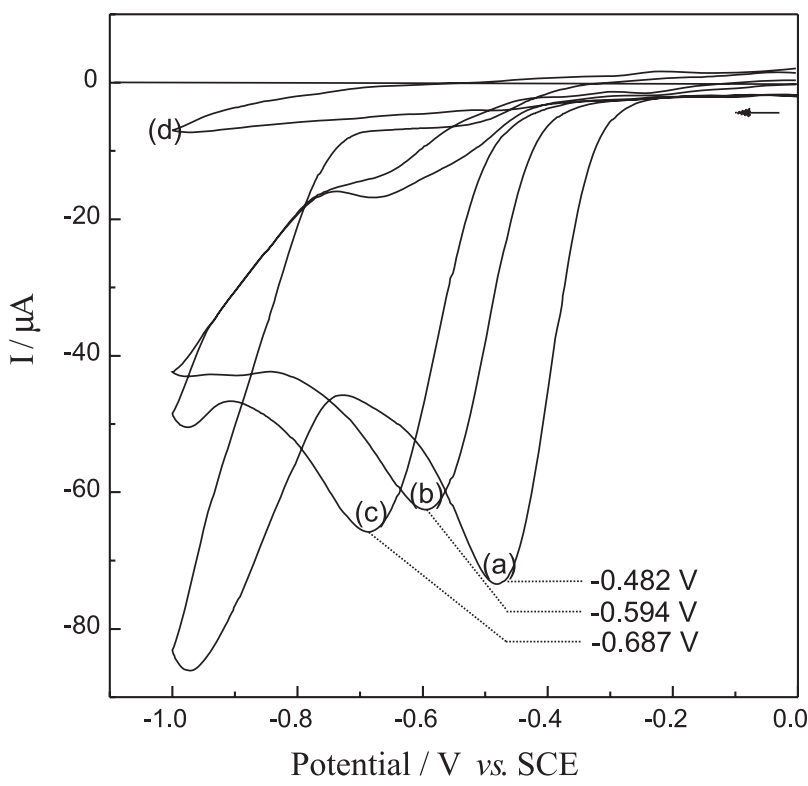

Figure 5. Cyclic voltammograms of (a) 3,5-DNSA: $\mathrm{E}_{\mathrm{p}}=-0.482 \mathrm{~V}$ at $\mathrm{pH}$ $=2.53$; (b) 3-NSA: $\mathrm{E}_{\mathrm{pc}}=-0.594 \mathrm{~V}$ at $\mathrm{pH}=2.85$; (c) $5-\mathrm{NSA}: \mathrm{E}_{\mathrm{pc}}=-0.687$ $\mathrm{V}$ at $\mathrm{pH}=2.80$; and (d) SALA (not electroactive) at $\mathrm{pH}$ range of 2.90 to 10.97 . exhibits a single, pH-dependent and irreversible 4electron polarographic wave in aqueous media below $\mathrm{pH}$ 5. This 4-electron wave is accompanied by a second 2-electron wave at more negative potentials giving way to p-aminophenol, formed by rearrangement of phenylhydroxylamine. ${ }^{34}$

The cathodic peak potential of all irreversible obtained voltammograms (Figures 5 to 9 ) showed a similar potential at acidic $\mathrm{pH}$ values (from 2.4 to 3.7 ) with $\mathrm{E}_{\mathrm{pc}}$ varying from $\sim-480 \mathrm{mV}$ to $\sim-1000 \mathrm{mV}$ depending on the ligand, when the metal to ligand ratio increased from $1: 1$ to $1: 3$ metal to ligand ratios, indicating more difficulty in reducing $\mathrm{ML}_{2}$ than $\mathrm{ML}$.

In Figure 6 the SALA complexes voltammograms are shown with varying $\mathrm{pH}$ in 1:1 metal to ligand ratio. In all metal to ligand ratios studied, the voltammograms showed a pseudo-reversible curves at low $\mathrm{pH}$ values (from 2.88 to 3.32 ) and above $\mathrm{pH}=5$ it was observed undefined regions impossible to visualize neither the cathodic nor the anodic peaks.

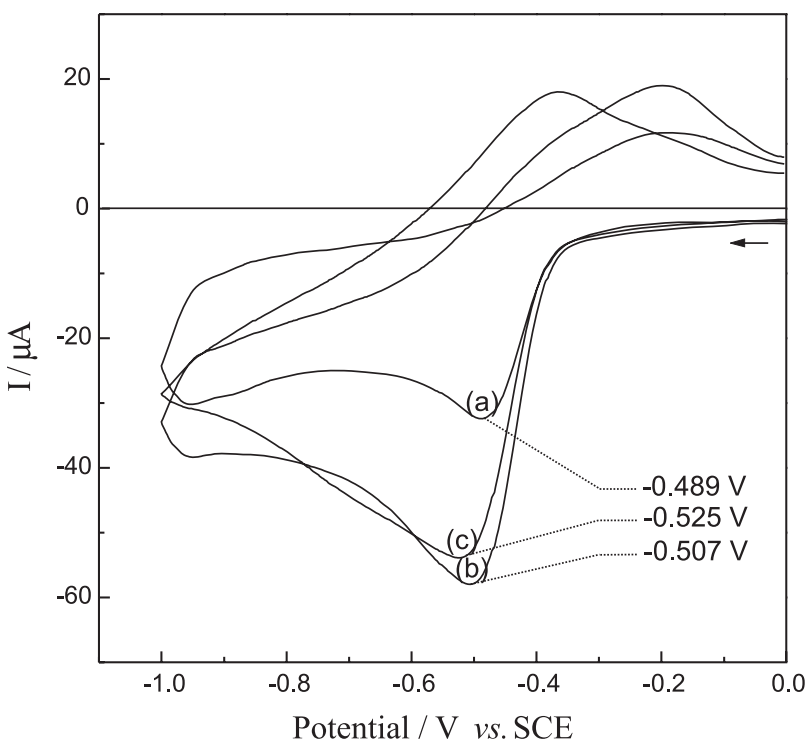

Figure 6. Cyclic voltammograms of (a) $[\mathrm{M}(\mathrm{SALA})](1: 1): \mathrm{E}_{\mathrm{pc}}=-0.489$ $\mathrm{V}$ at $\mathrm{pH}=3.32$; (b) $\left[\mathrm{M}(\mathrm{SALA})_{2}\right](1: 2): \mathrm{E}_{\mathrm{pc}}=-0.507 \mathrm{~V}$ at $\mathrm{pH}^{\mathrm{pc}}=2.96$; (c) [M:SALA] (1:3): $\mathrm{E}_{\mathrm{pc}}=-0.525 \mathrm{~V}$ at $\mathrm{pH}=2.88$.

In equation 10:

$\mathrm{E}_{1 / 2}=\mathrm{E}^{0}-0.059(\mathrm{~m} / \mathrm{n}) \mathrm{pH}$

$E_{1 / 2}$ is the half wave potential, $E^{O}$ is the standard potential at $298 \mathrm{~K}, m$ is the proton number, and $n$ is the electron number transferred in the redox process. Rearranging equation 10, equation 11 is obtained:

$\mathrm{m} / \mathrm{n}=\Delta \mathrm{E}_{\mathrm{pc}} /-0.059 \Delta \mathrm{pH}$ 
The value of $\mathrm{m} / \mathrm{n}=1.9976$ was found for the voltammogram of $\left[\mathrm{M}(\mathrm{SALA})_{2}\right]$ considering $E_{p c}=-0.507$ $\mathrm{V}$ for the voltammogram at $\mathrm{pH}=2.96$ (Figure 6-b) indicating that there are 2 protons for each electron transferred in the redox voltammetric process of $\left[\mathrm{M}(\mathrm{SALA})_{2}\right]$ (1:2 metal to ligand ratio), where one proton for each SALA ligand (total of 2 protons) and one electron for the complex may be transferred in this process. For the $[\mathrm{M}(\mathrm{SALA})]$ complex (1:1 metal to ligand ratio) the $m / n=1.0015$ indicates that there was one proton and one electron transferred in the whole process (Figure 6a).

In Figure 7 it is shown the cyclic voltammograms of 5-NSA and molybdenum suggesting a 1:1 metal to ligand ratio. Considering $E_{p c}=-0.494 \mathrm{~V}$ for the voltammogram at $\mathrm{pH}=3.17$ (Figure $7 \mathrm{a}$ ) and $E_{p c}=-0.575 \mathrm{~V}$ at $\mathrm{pH}=4.52$ of [M(5-NSA)] complex, it was determined a $\mathrm{m} / \mathrm{n}$ value of 1.0421 , indicating that there is 1 proton for each electron transferred in the whole redox voltammetric process of [M(5-NSA)] (1:1 metal to ligand ratio).

The cyclic voltammograms in Figure 8 present the 3NSA in the 1:1 metal to ligand ratio. Considering $E_{p c}=$ $-0.485 \mathrm{~V}$ for the voltammogram at $\mathrm{pH}=3.11$ (Figure 8a) and $E_{p c}=-0.564 \mathrm{~V}$ at $\mathrm{pH}=4.67$ of $[\mathrm{M}(3-\mathrm{NSA})]$ complex, the $\mathrm{m} / \mathrm{n}$ value was calculated, 0.9452 . This indicates that there is 1 proton for each electron transferred in the whole redox voltammetric process of [M(3-NSA)] (1:1 metal to ligand ratio).

Figure 9 presents the cyclic voltammograms of molybdenum and 3,5-DNSA in the ratio 1:1. A second and a third peaks were observed in this voltammogram,

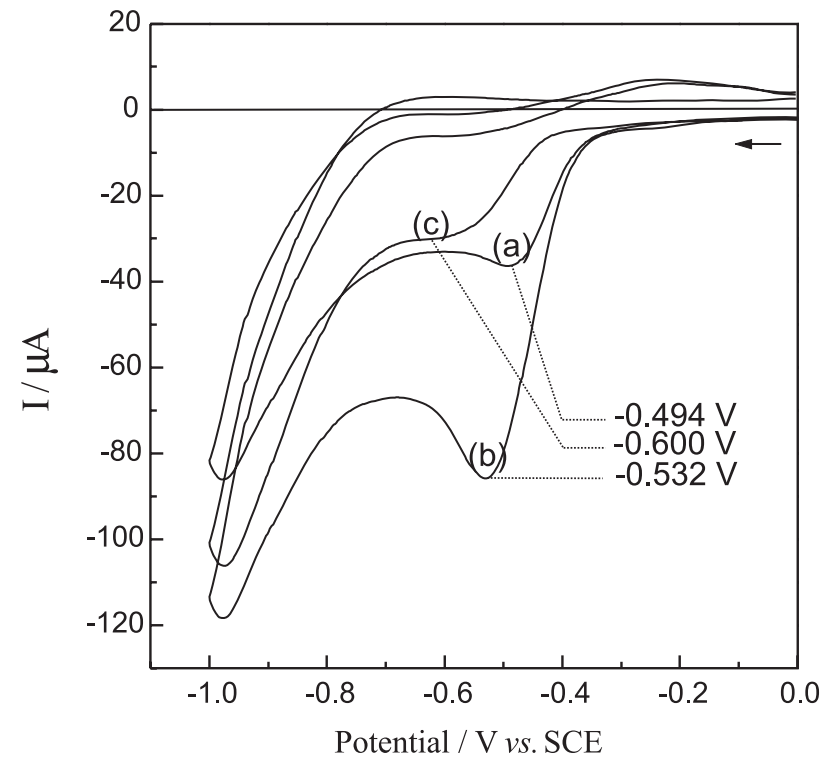

Figure 7. Cyclic voltammograms of (a) $[\mathrm{M}(5-\mathrm{NSA})](1: 1)$ : $\mathrm{E}_{\mathrm{pc}}=-0.494$ $\mathrm{V}$ at $\mathrm{pH}=3.17$; (b) $\left[\mathrm{M}(5-\mathrm{NSA})_{2}\right](1: 2): \mathrm{E}_{\mathrm{pc}}=-0.532 \mathrm{~V}$ at $\mathrm{pH}^{\mathrm{pc}}=2.71$; (c) [M:5-NSA] (1:3): $\mathrm{E}_{\mathrm{pc}}=-0.600 \mathrm{~V}$ at $\mathrm{pH}=3.73$.

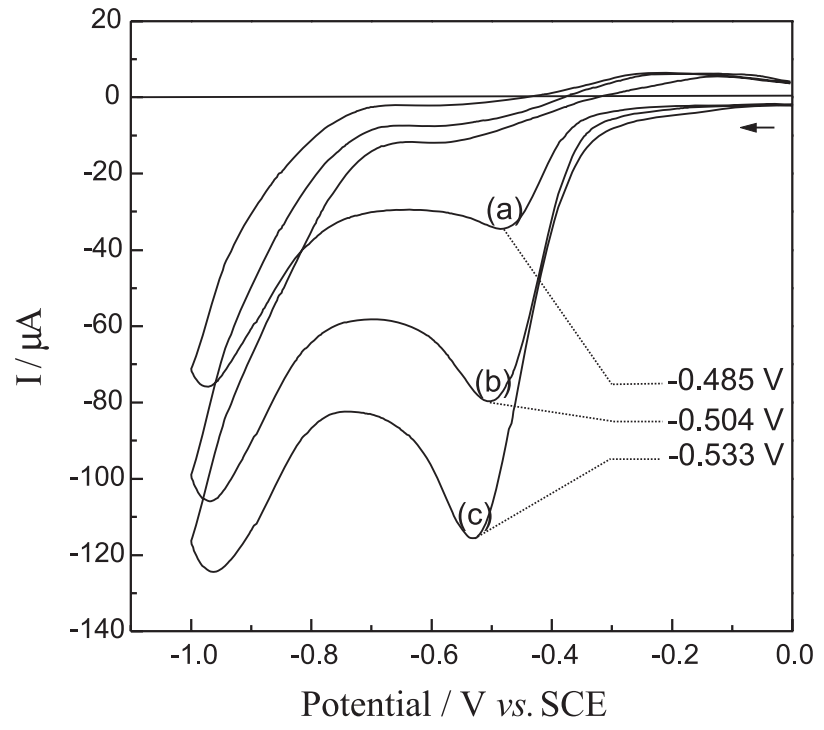

Figure 8. Cyclic voltammograms of (a) $[\mathrm{M}(3-\mathrm{NSA})](1: 1): \mathrm{E}_{\mathrm{pc}}=-0.485$ $\mathrm{V}$ at $\mathrm{pH}=3.11$; (b) $\left[\mathrm{M}(3-\mathrm{NSA})_{2}\right](1: 2): \mathrm{E}_{\mathrm{pc}}=-0.504 \mathrm{~V}$ at $\mathrm{pH}=2.66$; (c) [M:3-NSA] (1:3): $\mathrm{E}_{\mathrm{pc}}=-0.533 \mathrm{~V}$ at $\mathrm{pH}=2.41$.

$\mathrm{E}_{\mathrm{pc}}=-0.75 \mathrm{~V}$ and at $-0.975 \mathrm{~V}$, the latter being assigned to the second nitro group being reduced in 3,5-DNSA ligand.

Although the metal to ligand ratios of 1:3 have shown different values for $\mathrm{E}_{\mathrm{pc}}$ than any other metal to ligand ratio studied (Figure not shown), it was not possible to identify new species formed in this proportion neither by the cyclic voltammetry nor by potentiometric titrations. $\mathrm{C}$ items in Figures 5 to 9 are due to the uptaking of protons by the molybdate anion as well as the complexation at some extent by the system of any metal to ligand ratio.

The species distribution diagrams of all ligands in the presence of the metal ion were obtained (Figures not

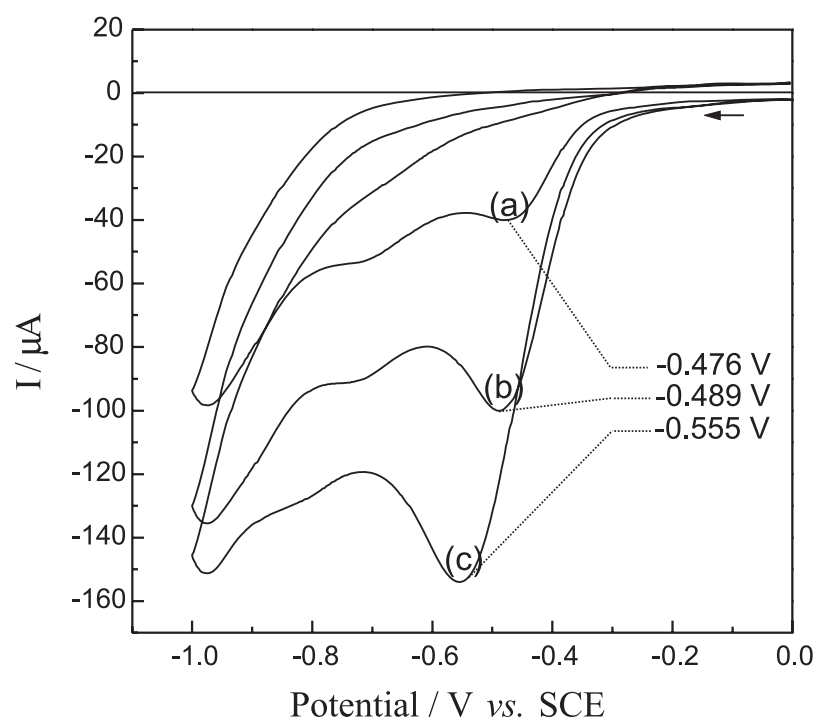

Figure 9. Cyclic voltammograms of (a) $[\mathrm{M}(3,5-\mathrm{DNSA})](1: 1): \mathrm{E}_{\mathrm{pc}}=$ $-0.476 \mathrm{~V}$ at $\mathrm{pH}=2.99$; (b) $\left[\mathrm{Mo}(3,5-\mathrm{DNSA})_{2}\right](1: 2): \mathrm{E}_{\mathrm{pc}}=-0.489 \mathrm{~V}$ at $\mathrm{pH}$ $=2.58$; (c) $[\mathrm{M}: 3,5-\mathrm{DNSA}](1: 3): \mathrm{E}_{\mathrm{pc}}=-0.555 \mathrm{~V}$ at $\mathrm{pH}=2.38$. 
shown) using the input of potentiometric data calculations in SPE program. ${ }^{30}$

The maximum peak absorbances, shoulders and isosbestic points of the UV-Vis spectra of all ligands and the metal ion are collected in Tables 3 to 6 . Aliquots of $\mathrm{pH}$ varying from 2 to 12 were taken and analysed by UVVis spectroscopy of all ligands (Supplementary Figure S1, and each ligand in the presence of the metal ion, SALA, 3-NSA and 3,5-DNSA, supplementary Figures S2, S3 and $\mathrm{S} 4$, respectively) where it can be seen changes in the spectra due to complexed species in agreement with the species distribution diagrams. At $\mathrm{pH}$ values far below and far above those shown, no significant presence of complexed species were detected in the equilibria studied as the spectra in these values showed a sharp decrease in the charge transfer bands characteristic of the Molybdenum complexes with the nitro ligands studied $(300-370 \mathrm{~nm})$ and SALA $(270-300 \mathrm{~nm}){ }^{35}$

The spectra of HL and L forms of SALA are at $\mathrm{pH}$ values of 4.67 and 12.19, where there are the presence of one deprotonated and the fully deprotonated forms, respectively (refer to Table 3 ). The spectra of $\mathrm{MoO}_{4}^{2-}$ $\left(\mathrm{MO}_{2}\right)$ alone has shown at $\mathrm{pH}=5.45$ the cation $\mathrm{MoO}_{2}^{2+}$ (M) form which is the responsible for the complexed species found in all studied systems. The $\mathrm{pH}$ values of 4.07 and 5.52 represent the spectra of the complexed forms MHL and ML, respectively, in the 1:1 metal:SALA ratio. In 1:2 metal to ligand ratio it is seen the formation of $\mathrm{ML}_{2}(\mathrm{pH}=6.86)$. In the 1:3 metal:SALA ratio it is seen both at $\mathrm{pH} 4.16$ and 10.19 that other species rather than
ML, MHL or $\mathrm{ML}_{2}$ are present, but it was not possible to clearly identify them by potentiometric titrations under the experimental conditions employed, as the equilibrium in those $\mathrm{pH}$ values might be a mixture of all species involving polyanions in the former $\mathrm{pH}$ value and hydrolysis products in the basic $\mathrm{pH}$ value.

The UV-Vis spectra of HL and $\mathrm{L}$ were taken at $\mathrm{pH}$ 4.66 and 10.63 (refer to Table 4) of 3-NSA. The potentiometric profile and the complete UV-Vis spectra of 3-NSA are published elsewhere. ${ }^{26} \mathrm{In} \mathrm{pH}$ values of 4.11, 4.77 in 1:1 metal:3-NSA ratio shows the complexed species MHL and ML. In 1:2 metal to ligand ratio the $\mathrm{UV}-\mathrm{Vis}$ spectra taken at $\mathrm{pH}=5.01$ depict the ML species and in 1:3 ratio at acidic and basic $\mathrm{pH}$ values there is a mixture of species including hydrolytic ones in the equilibrium (refer to supplementary Figure S3).

The UV-Vis spectra of HL and $\mathrm{L}$ were taken at $\mathrm{pH}$ 4.74 and 10.81 of 5-NSA, respectively (refer to Table 5). The $\mathrm{pH}$ values of $4.10,6.74$ and 8.24 refer to the complexed forms $\mathrm{MHL}, \mathrm{ML}, \mathrm{ML}_{2}$ in metal:5-NSA ratios of $1: 1,1: 1$ and $1: 2$, respectively.

The UV-Vis spectra of HL and L forms of 3,5-DNSA was presented at $\mathrm{pH}=4.42$ and 7.32 , respectively. The $\mathrm{pH}$ values of 4.71 and 7.01 refer to the complexed forms MHL, ML being coincidental the two obtained curves due to an almost equimolar presence of MHL and ML from $\mathrm{pH} 4$ to 7 . In metal to 3,5-DNSA 1:2 ratio, $\mathrm{ML}_{2}$ is present at $\mathrm{pH}$ around 7.6 (refer to Table 1).

The great number of isosbestic points in all taken UVVis spectra indicating interconvertion of complexed

Table 3. UV-Vis spectra of SALA (0:1), SALA and M at different metal to ligand (L) ratios and metal (1:0), with varying pH values

\begin{tabular}{|c|c|c|c|c|c|c|c|c|}
\hline $\mathrm{MoO}_{2}: \mathrm{L}^{\mathrm{pH}}$ & 4.07 & 5.52 & 6.86 & 4.67 & 12.39 & 4.34 & 5.45 & 10.34 \\
\hline $0: 1$ & $\mathrm{X}$ & $\mathrm{X}$ & $\mathrm{X}$ & $\begin{array}{l}206 \mathrm{~m} \\
300 \mathrm{~m} \\
230 \mathrm{sh} \\
204 \mathrm{i} \\
216 \mathrm{i}\end{array}$ & $\begin{array}{l}203 \mathrm{~m} \\
298 \mathrm{~m} \\
230 \mathrm{sh} \\
204 \mathrm{i} \\
216 \mathrm{i}\end{array}$ & $X$ & $X$ & $\mathrm{X}$ \\
\hline $1: 0$ & $\mathrm{X}$ & $\mathrm{X}$ & $\mathrm{X}$ & $X$ & $X$ & $\begin{array}{l}208 \mathrm{~m} \\
206 \mathrm{~m}\end{array}$ & $\begin{array}{l}208 \mathrm{~m} \\
225 \mathrm{sh}\end{array}$ & $\begin{array}{l}198 \mathrm{~m} \\
230 \mathrm{sh} \\
225 \mathrm{sh}\end{array}$ \\
\hline $1: 1$ & $\begin{array}{l}205 \mathrm{~m} \\
280 \mathrm{sh} \\
240 \mathrm{i}\end{array}$ & $\begin{array}{l}230 \mathrm{~m} \\
295 \mathrm{~m} \\
240 \mathrm{i}\end{array}$ & $\mathrm{X}$ & $X$ & $X$ & $X$ & $X$ & $\mathrm{X}$ \\
\hline $1: 2$ & $\mathrm{X}$ & $\mathrm{X}$ & $\begin{array}{l}208 \mathrm{~m} \\
295 \mathrm{~m} \\
194 \mathrm{sh} \\
225 \mathrm{sh} \\
220 \mathrm{i}\end{array}$ & $X$ & $\mathrm{X}$ & $\mathrm{X}$ & $X$ & $X$ \\
\hline $1: 3$ & $\begin{array}{l}206 \mathrm{~m} \\
295 \mathrm{~m} \\
220 \mathrm{sh}\end{array}$ & $\mathrm{X}$ & $\mathrm{X}$ & $X$ & $X$ & $X$ & $X$ & $\begin{array}{l}208 \mathrm{~m} \\
295 \mathrm{~m} \\
220 \mathrm{sh}\end{array}$ \\
\hline
\end{tabular}

$\mathrm{m}=$ maximum peak absorbance; $\mathrm{sh}=$ shoulder; $\mathrm{i}=\mathrm{i}$ sosbestic point. 
Table 4. UV-Vis spectra of 3-NSA (0:1) and 3-NSA and M at different metal to ligand $(\mathrm{L})$ ratios, with varying $\mathrm{pH}$ values

\begin{tabular}{|c|c|c|c|c|}
\hline $\mathrm{MoO}_{2}: \mathrm{L}^{\mathrm{pH}}$ & 4.11 & 4.77 & 5.01 & 10.93 \\
\hline $0: 1$ & $X$ & $\begin{array}{c}200 \mathrm{~m} \\
225 \mathrm{~m} \\
350 \mathrm{~m} \\
395 \mathrm{i}\end{array}$ & $\mathrm{X}$ & $\begin{array}{c}198 \mathrm{~m} \\
220 \mathrm{sh} \\
395 \mathrm{i}\end{array}$ \\
\hline $1: 1$ & $\begin{array}{c}207 \mathrm{~m} \\
227 \mathrm{~m} \\
348 \mathrm{~m} \\
95 \mathrm{sh} \\
250 \mathrm{sh} \\
225 \mathrm{i} \\
237 \mathrm{i}\end{array}$ & $\begin{array}{c}207 \mathrm{~m} \\
227 \mathrm{~m} 1 \\
195 \mathrm{sh} \\
225 \mathrm{i} \\
237 \mathrm{i}\end{array}$ & X & $X$ \\
\hline $1: 2$ & $X$ & $\mathrm{X}$ & $\begin{array}{c}210 \mathrm{~m} \\
348 \mathrm{~m} \\
227 \mathrm{sh} \\
225 \mathrm{i} \\
237 \mathrm{i} \\
246 \mathrm{i} \\
285 \mathrm{i}\end{array}$ & $X$ \\
\hline $1: 3$ & $\begin{array}{c}203 \mathrm{~m} \\
350 \mathrm{~m} \\
220 \mathrm{sh} \\
218 \mathrm{i} \\
232 \mathrm{i} \\
244 \mathrm{i} \\
285 \mathrm{i} \\
310 \mathrm{i} \\
380 \mathrm{i}\end{array}$ & $X$ & $\mathrm{X}$ & $\begin{array}{c}206 \mathrm{~m} \\
222 \mathrm{sh} \\
218 \mathrm{i} \\
232 \mathrm{i} \\
244 \mathrm{i} \\
285 \mathrm{i} \\
310 \mathrm{i} \\
380 \mathrm{i}\end{array}$ \\
\hline
\end{tabular}

$\mathrm{m}=$ maximum peak absorbance; $\mathrm{sh}=$ shoulder; $\mathrm{i}=\mathrm{i}$ sosbestic point.

Table 5. UV-Vis spectra of 5-NSA (0:1) and 5-NSA and M at different metal to ligand $(\mathrm{L})$ ratios, with varying $\mathrm{pH}$ values

\begin{tabular}{|c|c|c|c|c|c|c|c|}
\hline $\mathrm{MoO}_{2}: \mathrm{LH}$ & 4.10 & 6.74 & 8.24 & 6.05 & 10.21 & 4.74 & 10.81 \\
\hline $0: 1$ & $X$ & $X$ & $X$ & $X$ & X & $\begin{array}{c}198 \mathrm{~m} \\
314 \mathrm{~m} \\
220 \mathrm{sh} \\
366 \mathrm{i}\end{array}$ & $\begin{array}{c}196 \mathrm{~m} \\
406 \mathrm{~m} \\
366 \mathrm{i}\end{array}$ \\
\hline $1: 1$ & $\begin{array}{c}208 \mathrm{~m} \\
225 \mathrm{~m} \\
305 \mathrm{~m} \\
225 \mathrm{i} \\
355 \mathrm{i}\end{array}$ & $\begin{array}{c}208 \mathrm{~m} \\
228 \mathrm{~m} \\
315 \mathrm{~m} \\
225 \mathrm{i} \\
355 \mathrm{i}\end{array}$ & $\mathrm{X}$ & $\mathrm{X}$ & $\mathrm{X}$ & $\mathrm{X}$ & $X$ \\
\hline $1: 2$ & $\mathrm{X}$ & $X$ & $\begin{array}{c}208 \mathrm{~m} \\
315 \mathrm{~m} \\
229 \mathrm{sh} \\
215 \mathrm{i} \\
238 \mathrm{i} \\
276 \mathrm{i} \\
354 \mathrm{i}\end{array}$ & $X$ & $X$ & $X$ & $\mathrm{X}$ \\
\hline $1: 3 X$ & $\mathrm{X}$ & $\mathrm{X}$ & $209 \mathrm{i}$ & $\begin{array}{c}204 \mathrm{~m} \\
315 \mathrm{~m} \\
410 \mathrm{~m} \\
220 \mathrm{i} \\
238 \mathrm{i} \\
354 \mathrm{i}\end{array}$ & $\begin{array}{c}202 \mathrm{~m} \\
315 \mathrm{~m} \\
\mathrm{X} \\
222 \mathrm{sh} \\
354 \mathrm{i}\end{array}$ & $X$ & \\
\hline
\end{tabular}

$\mathrm{m}=$ maximum peak absorbance; $\mathrm{sh}=$ shoulder; $\mathrm{i}=$ isosbestic point . species, coincided with the $\mathrm{pH}$ and species presented by the distribution diagrams. It was seen that 3,5-DNSA has a sterical difficulty in forming $\mathrm{ML}_{2}$ species even presenting a stability constant similar to 3 -NSA. This can be explained by the small percentage of formation in the equilibrium of this species.

The change in the CV and UV-Vis spectra caused by complex formation was used to support potentiometric data and was not used to calculate formation constants. Other complexed species were suggested by UV-Vis and $\mathrm{CV}$ analyses but it was not attempted to characterize them due to the large number of species in the equilibria as well as in the spectra. Some proposed complexes had a M:L ratio of 2:2, 2:1 and 4:2, as well as their protonated counterparts. The variation in the stoichiometry can be a direct consequence of the behaviour of molybdate and this metal ion towards $\alpha$-hydroxycarboxylate ligands as previously reported. ${ }^{35,36}$

Table 6. UV-Vis spectra of 3,5-NSA (0:1) and 3,5-NSA and M at different metal to ligand $(\mathrm{L})$ ratios, with varying $\mathrm{pH}$ values

\begin{tabular}{|c|c|c|c|c|c|}
\hline $\mathrm{MoO}_{2}: \mathrm{L}^{\mathrm{pH}}$ & 4.42 & 8.91 & 4.71 & 7.01 & 7.65 \\
\hline $0: 1$ & $\begin{array}{c}198 \mathrm{~m} \\
330 \mathrm{~m} \\
210 \mathrm{sh} \\
354 \mathrm{i}\end{array}$ & $\begin{array}{c}198 \mathrm{~m} \\
385 \mathrm{~m} \\
354 \mathrm{i}\end{array}$ & $X$ & $X$ & $\mathrm{X}$ \\
\hline & & & $\begin{array}{l}205 \mathrm{~m} \\
225 \mathrm{~m}\end{array}$ & $\begin{array}{l}205 \mathrm{~m} \\
225 \mathrm{~m}\end{array}$ & \\
\hline $1: 1$ & $X$ & $X$ & $\begin{array}{c}328 \mathrm{~m} \\
240 \mathrm{i} \\
344 \mathrm{i}\end{array}$ & $\begin{array}{c}356 \mathrm{~m} \\
240 \mathrm{i} \\
344 \mathrm{i}\end{array}$ & $X$ \\
\hline $1: 2$ & $X$ & $\mathrm{X}$ & $\mathrm{X}$ & $X$ & $\begin{array}{c}206 \mathrm{~m} \\
230 \mathrm{~m} \\
369 \mathrm{~m} \\
220 \mathrm{sh} \\
215 \mathrm{i} \\
344 \mathrm{i}\end{array}$ \\
\hline
\end{tabular}

$\mathrm{m}=$ maximum peak absorbance; $\mathrm{sh}=$ shoulder; $\mathrm{i}=$ isosbestic point.

\section{Conclusions}

The use of this study showed the existence of at least one complexed model species of HA and NHA with molybdenum (VI) at a $\mathrm{pH}$ value commonly found in soil. Use of a salicylic acid model may contribute to the understanding of other complexed species involving this metal ion in aqueous solutions with varying $\mathrm{pH}$ values.

Making a comparison among salicylic HA and nitrosalicylic model compounds and ligands derived from phthalic and nitrophthalic based model compounds, the presence of the complexed species is seen in $\mathrm{pH}$ values until 8 only for the salicylic derived models and 4- 
nitrocatechol, since the complexed species for phthalic derivatives are decomposed after $\mathrm{pH} 6.5 .^{5}$

The nitro compounds are weaker Lewis bases than the non nitro model compound - SALA, due to the electron withdrawing effect of $-\mathrm{NO}_{2}$ in the aromatic ring. ${ }^{5}$ Nonetheless, the nitrohumic substances, laboratory artifacts, presented as an alternative fertilizer by providing more $\mathrm{N}$ content when the mineralization of the soil occur, can also bind differently to metal ions when compared to non nitro organic matter in a wider range of $\mathrm{pH}$ values.

\section{Acknowledgments}

The authors thank Universidade Federal do Paraná, UFPR, CNPq for scholarships and the Electrical Company of Paraná (Copel), PR.

\section{Supplementary Information}

UV-Vis spectra of all ligands, $10^{-4} \mathrm{~mol} \mathrm{~L}^{-1}$. SALA, 3NSA, 5-NSA, 3,5-DNSA and $\mathrm{MoO}_{2}{ }^{2+}(\mathrm{M})$ at various $\mathrm{pH}$ values (Figure S1), SALA and SALA and $\mathrm{MoO}_{2}{ }^{2+}(\mathrm{M})$, both at $10^{-4} \mathrm{~mol} \mathrm{~L}^{-1}$ at various $\mathrm{pH}$ values (Figure $\mathrm{S} 2$ ), of 3NSA and 3-NSA and $\mathrm{MoO}_{2}^{2+}(\mathrm{M})$ at various $\mathrm{pH}$ values (Figure S3) and 3,5-DNSA and 3,5-DNSA and $\mathrm{MoO}_{2}{ }^{2+}$ (M) at various $\mathrm{pH}$ values (Figure $\mathrm{S} 4$ ) are available free of charge as PDF file at http://jbcs.sbq.org.br.

\section{References}

1 . Donahue, J.P.; Lorber, C.; Nordlander, E.; Holm, R.H.; J. Am. Chem. Soc. 1998, 120, 3259.

2. da Silva, J.J.R.F.; Williams, R.J.P.; The Biological Chemistry of the Elements. The Inorganic Chemistry of Life, Clarendon Press: Oxford, 1997, pp. 416-427.

3. Prasad, S.; Guimarães, T.L.M.; J. Braz. Chem. Soc. 1998, 9, 253.

4. Petterson, L.; Andersson, I.; Öhman, L-O.; Acta Chem. Scand. 1985, 39, 53.

5. Mercê, A.L.R.; Greboge, C.; Mendes, G.; Mangrich, A.S.; J. Braz. Chem. Soc. 2005, 16, 37.

6. Sposito, G.; The Chemistry of Soils, Oxford University Press: New York, 1989.

7. Schnitzer, M.; Soil Sci. 1991, 151, 41.

8. Schulten, H. R.; Schnitzer, M.; Soil Sci. Soc. Am. J. 1991, 56, 1811.

9. Schulten, H. R.; Schnitzer, M.; Naturwissenschaften 1995, 82, 487.

10. Fukushima, M.; Tanaka, S.; Nakamura, H.; Ito, S.; Haraguchi, K.; Ogata, T.; Anal. Chim. Acta 1996, 322, 173.

11. Sposito, G.; CRC Critical Rev. in Environm. Control 1997, 16, 193. And references cited therein.
12. Bryan, N.D.; Hesketh, N.; Livens, F.R.; Tipping, E.; Jones, M. N.; J. Chem. Soc., Faraday Trans. 1998, 94, 95.

13. Jones, M.N.; Bryan, N.D.; Adv. Colloid Interface Sci. 1998, 78,1 .

14. Saar, R.A.; Weber, J.H.; Environ. Sci. Technol. 1982, 16, 510A.

15. Chakrabarti, C.L.; Lu, Y.; Cheng, J.; Anal. Chim. Acta 1993, 267, 47.

16. Warwick, P.; Hall, A.; Pashley, V.; Van der Lee, J.; Maes, A.; Chemosphere 1998, 36, 2283.

17. Kam, S-K.; Gregory, J.; Water Res. 2001, 35, 3557.

18. Takahashi, Y.; Minai, Y.; Ambe, S.; Makide, Y.; Ambe, F.; Tominaga, T.; Sci. Total Environ. 1997, 198, 61.

19. Vasconcelos, M.T.S.D.; Gomes, C.A.R.; Eur. Polym. J. 1997, $33,631$.

20. Kinniburgh, D.G.; van Riemsdijk, W.H.; Koopal, L.K.; Borkovec, M.; Benedetti, M.F.; Avena, M.J.; Colloids Surf., A 1999, 151, 147.

21. Gustafsson, J.P.J.; Colloid Interface Sci. 2001, 244, 102.

22. Hamilton-Taylor, J.; Postill, A.S.; Tipping, E.; Harper, M.P.; Geochim. Cosmochim. Acta 2002, 66, 403.

23. Guthrie, J.W.; Mandal, R.; Salam, M.S.A.; Hassan, N.M.; Murimboh, J.; Chakrabarti, C.L.; Back, M.H.; Grégoire, D.C.; Anal. Chim. Acta 2003, 480, 157.

24. Borrok, D.; Fein, J.B.; Geochim. Cosmochim. Acta 2004, 68, 3043.

25. Zhou, P.; Yan, H.; Gu, B.; Chemosphere 2005, 58, 1327.

26. Mercê, A.L.R.; Mangrich, A.S.; Szpoganicz, B.; Levy, N.M.; Felcman, J.; J. Braz. Chem. Soc. 1996, 7, 97.

27. Mercê, A.L.R.; Mangrich, A.S.; Szpoganicz, B.; Levy, N.M.; Felcman, J.; J. Braz. Chem. Soc. 1996, 7, 239.

28. Mercê, A.L.R.; Spir, I.H.Z.; Salmón, M.J.O.; Giannoni, R.A.; Mangrich, A.S.; J. Braz. Chem. Soc. 1999, 10, 463.

29. Schwarzenbach, G.; Flaschka, H.; Complexometric Titrations, Methuen and Co Ltda: UK, 1969, p. 225.

30. Martell, A. E.; Motekaitis R.J.; The Determination and Use of Stability Constants, VCH: New York, 1992.

31. Baes Jr., C.F.; Mesmer, R.E.; The Hydrolysis of Cations, JohnWiley and Sons: New York, 1976.

32. Farkas, E.; Csóka, H.; Micera, G.; Dessi, A.; J. Inorg. Biochem. 1997, 65, 281.

33. Cruywagen, J.J; Rohwer, E.A.; Wessels, G.F.S.; Polyhedron 1995, 23, 3481.

34. Marken, F.; Kumbhat, S.; Sanders, G.H.W.; Compton, R.G.; J. Electroanal. Chem., 1996, 411, 95.

35. Farkas, E.; Megyeri, K.; Somsák, L.; Kovács, L.; J. Inorg. Biochem. 1998, 70, 41

36. Cruywagen, J.J.; Rohwer, E.A.; van de Water, R.F.; Polyhedron 1997, 16, 243. 


\title{
Molybdenum (VI) Binded to Humic and Nitrohumic Acid Models in Aqueous Solutions. Salicylic, 3-Nitrosalicylic, 5-Nitrosalicylic and 3,5 Dinitrosalicylic Acids, Part 2
}

\author{
Ana Lucia R. Mercê, ${ }^{*, a}$ Priscilla P. Lopes, ${ }^{a}$ Antonio S. Mangrich ${ }^{a}$ and Noel M. Levy ${ }^{b}$ \\ ${ }^{a}$ Departamento de Química - Centro Politécnico, Universidade Federal do Paraná CP 19081, \\ 81531-990 Curitiba-PR, Brazil \\ ${ }^{b}$ Companhia Paranaense de Energia (COPEL), Curitiba - PR, Brazil
}

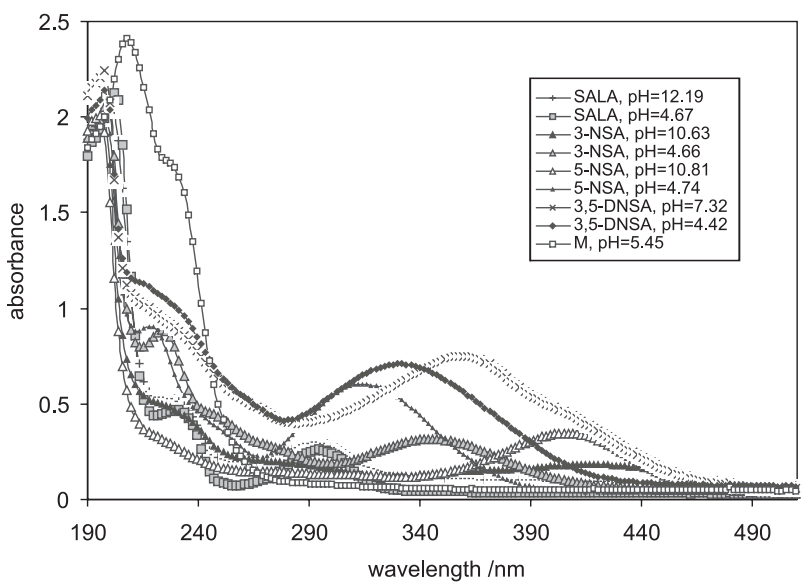

Figure 1S. UV-Vis spectra of ligands, $10^{-4} \mathrm{~mol} \mathrm{~L}^{-1}$. SALA, 3-NSA, 5NSA, 3,5-DNSA and $\mathrm{M}$ at various $\mathrm{pH}$ values.

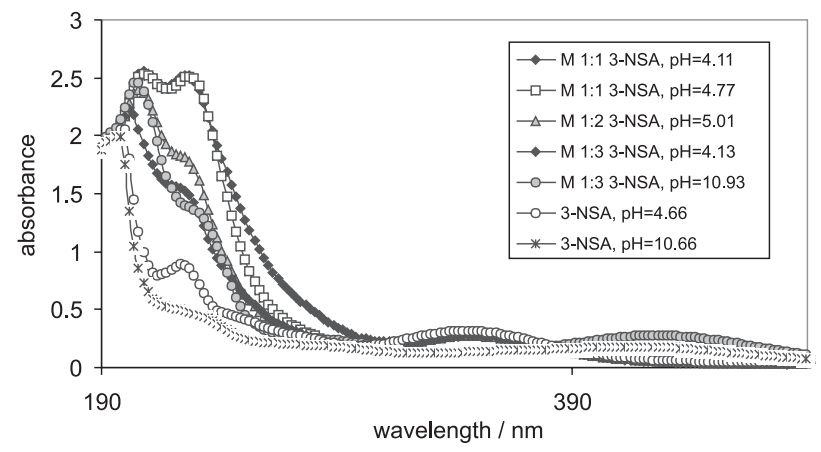

Figure 3S. UV-Vis spectra of 3-NSA and 3-NSA and $\mathrm{M}$ at various $\mathrm{pH}$ values.

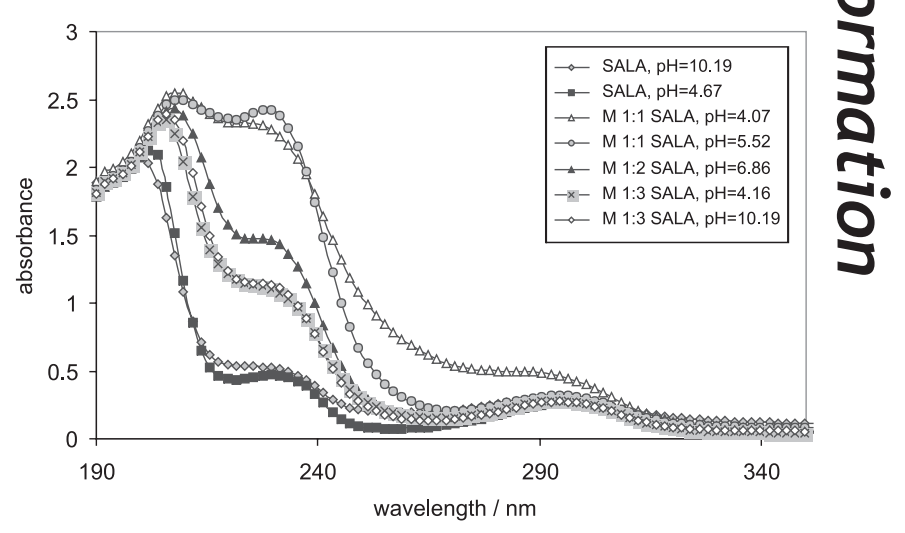

Figure 2S. UV-Vis spectra of SALA and SALA and M, both at $10^{-4} \mathrm{~mol}$ $\mathrm{L}^{-1}$ at various $\mathrm{pH}$ values.

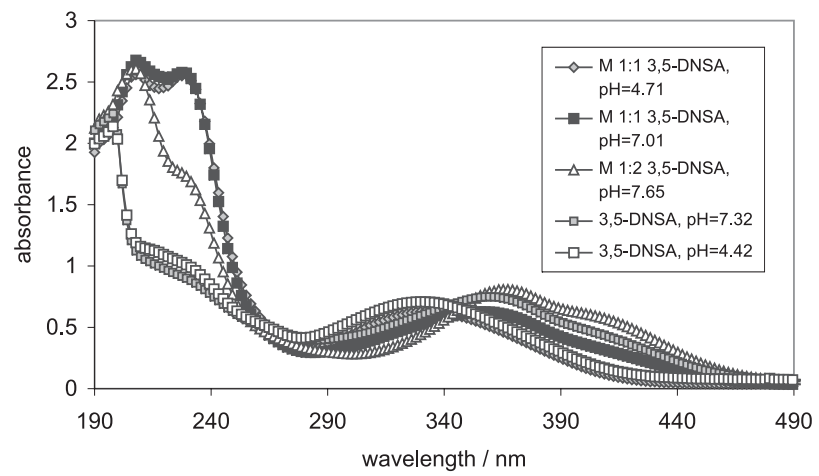

Figure 4S. UV-Vis spectra of 3,5-DNSA and 3,5-DNSA and M at various $\mathrm{pH}$ values.

*e-mail: anamerce@ufpr.br 